\title{
Impact of Tax Revenue on Economic Growth in Nigeria
}

\author{
Chukwuemeka Nwamuo, Ph.D \\ Department of Economics, Obong University, Obong Ntak, Akwalbom state - Nigeria
}

\begin{abstract}
The study investigated the impact of tax revenue on economic growth in Nigeria, Annual time series data were obtained from the Central Bank of Nigeria Statistical Bulletin for the period 1981 to 2015 on the variables used for the study. Unit root test was conducted using Augmented Dickey-Fuller test technique and the result showed that the variables were stationary though at different levels. Co-integration test was also conducted using Johanssen co-integration test method and the result showed that the variables in the model were co-integrated meaning that the variables have a long run relationship. The regression result showed that petroleum profit tax, company income tax and custom and excise duty have a positive and insignificant impact on the economic growth in Nigeria. Non oil revenue has a positive and significant impact on the economic growth in Nigeria. The R-squared value showed that about 98.4 percent of the total variations in the dependent variable were explained by changes in the explanatory variables. The error correction result showed that the speed of adjustment to long run equilibrium is 52.4 percent when any past deviation must be corrected in the present period. Based on the findings, it was recommended that government agencies responsible for administration and collection of taxes should ensure that there is effective supervision and monitoring of all taxable activities so as to ensure that tax avoidance and tax evasion are reduced as this will help in generating more tax revenue for the government. Government should also ensure that all revenues collected (tax revenues and non-oil revenue) are transparently accounted for. Moreover, government should ensure tax revenues collected are used to provide adequate social amenities to the citizens as this will motivate them in complying to tax laws.
\end{abstract}

Keywords: Petroleum profit tax, Company income tax, Tax revenue, Economic growth

DOI: $10.7176 / \mathrm{EJBM} / 11-24-02$

Publication date: August $31^{\text {st }} 2019$

1.1 Introduction: ` Tax plays a crucial role in the economic management of any nation. It is a major source of revenue for the government. Njoku (2009) defined tax as a compulsory contributions or payments of money or occasionally of goods and services from private individuals, institutions or groups to the governments for the defraying of expenditures incurred by the government in the common interest of all without reference to any special benefit conferred on any of the person or impersonal unit that made the compulsory contributions or payments. Dimoji, Atorudibo and Onwuneme (2013) see tax as the levy imposed on individuals and firms on goods and services by the government and other agencies. Bhatia (2009) defined tax as a compulsory levy payable by an economic unit to the government without any corresponding entitlement to receive a definite and direct quid pro quo from the government. According to Chinwoke (2014) tax is a compulsory payment made by individuals and institutions to the government while Soyode and Kajola (2015) defined tax as a compulsory exaction of money by a public authority for public purposes. In differentiating tax from taxation, Chinwoke (2014) defined taxation as the management and administration of tax while Njoku (2009) sees taxation as the act of levying tax on the taxable units or groups by the government, which has the sole authority to levy tax. Dimoji, Atorudibo and Onwuneme (2013) see taxation as the act or a way of imposing a compulsory levy by the government and other agencies on the individuals and firms or on goods and services. Anyanwu (1997) and Chinwoke (2014) are of the opinion that there are three principal objectives of taxation and they include: raising revenue for the government, regulating the economy and economic activities; and to control income and employment.

1.2 Statement of problem: Though government has different sources of revenue, but the most reliable source of government revenue is tax. Unfortunately the revue that government generates from tax over the years has not been adequate to finance its increasing social and public spending needed in stimulating economic growth in the country. This has been as a result of high rate of tax evasion and tax avoidance, leakages and falsification of records in Nigeria. The study therefore investigated the impact of tax revenue on the economic growth in Nigeria.

\subsection{Objectives of the study:}

The broad objective of the study was to investigate the impact of tax revenue on economic growth in Nigeria. The specific objectives of the study were:

(i) To examine the impact of petroleum profit tax on economic growth in Nigeria.

(ii) To investigate the impact of company income tax on economic growth in Nigeria.

( iii) To examine the impact custom and excise duty on economic growth in Nigeria. 
(iv) To investigate the impact of non oil revenue on economic growth in Nigeria

\subsection{Hypothesis of the Study:}

In order to guide the study, the following null hypotheses were formulated:

$\mathrm{HO}_{1}$ : Petroleum profit tax does not have any significant impact on economic growth in Nigeria.

$\mathrm{HO}_{2}$ : Company income tax does not have any significant impact on economic growth in Nigeria $\mathrm{HO}_{3}$ : Custom and excise duty does not have any significant impact on economic growth in Nigeria

$\mathrm{HO}_{4}$ : Non oil revenue does not have any significant impact on economic growth in Nigeria

\subsection{Theoretical literature}

2.1.1 Cost of service theory: According to cost of service theory, the cost incurred by the government in providing certain services to the people must collectively be met by the people who are the ultimate receivers of the services. This theory believes that tax is similar to price. So if a person does not utilize the services of a state, he should not be charged any tax. Hence the basis of taxation should be the cost of the different services rendered by the government to the taxpayers (Jhingan, 2010).

2.1.2 The benefits-received theory: This theory proceeds on the assumption that there is basically an exchange or contractual relationship between taxpayers and the state. The state provides certain goods and services to the members of the society and they contribute to the cost of these supplies in proportion to the benefits received. In this quid pro quo set up, there is no place for issues like equitable distribution of income and wealth. Instead the benefits received are taken to represent the basis for distributing the tax burden in a specific manner. This theory overlooks the possible use of tax policy for bringing about economic growth or economic stabilization in the country (Bhatia, 2009).

2.1.3 Ability to pay theory: The ability to pay principle of taxation is just, equitable and the most accepted theory of taxation. This theory proposes that those who possess income or wealth should contribute to the support of public functions according to their relative ability to pay. The burden of tax should be according to the ability of tax-payers. Those who have means to pay should pay and those who have not need not pay. There is the problem of measuring the ability to pay of a taxpayer (Jhingan, 2010).

\subsection{Conceptual literature}

A tax is a compulsory levy imposed on persons, corporate bodies, goods and services. It is a source of revenue to the government which is used in the provision of social services (Likita, 1999). Anyanwu (2003) sees tax as a compulsory payment to the government by individuals and corporation for the purpose of achieving one or more of the government objectives. Bhatia (2009) defined tax as a compulsory levy payable by an economic unit to the government without ant corresponding entitlement to receive a definite and direct quid pro quo from the government. Njoku (2009) also defined tax as a compulsory contributions or payments of money or occasionally of goods and services from private individuals, institutions or groups to the governments for the defraying of expenditures incurred by the government in the common interest of all without reference to any special benefit conferred on any of the person or impersonal unit that made the compulsory contributions or payments. Chinwoke (2014) defined taxation as the management and administration of tax while Njoku (2009) sees taxation as the act of levying tax on the taxable units or groups by the government, which has the sole authority to levy tax.

The objectives of taxation include: the redistribution of income and wealth, revenue generation, economic stabilization, protection of infant industries and promotion of economic growth and development (Okafor and Obasi 2011). According to Dewett and Navalur (2012), the principal social and economic objectives of taxation include redistribution of inequalities in income and wealth, accelerating economic growth and price stability. Likita (1999) further stressed that the objective of taxation are removal of poverty and inequality, reduction of consumption, promotion of private savings, correction of balance of payments deficit allocation of resources and source of revenue to the government. Soyode and Kajola (2015) see the objective of taxation to include promotion of fiscal responsibility and accountability, facilitation of economic growth and development, providing the government with stable resources for the provision of public goods and services, addressing inequalities in income distribution, providing economic stabilization, pursuing fairness and equity and Correcting market failures or imperfection.

Taxes can be classified in terms of the possibility of shifting the tax burden (Chinwoke (2014)). Anyanwu (1993) argued that taxes may be categorized on the basis of burden or incidence, viz: taxes imposed on net income taxes imposed on property and taxes imposed on production or sale of goods. Generally speaking, taxes are categorized into two broad groups depending on whether persons or things are taxed. These two broad categories of taxes are direct and indirect taxes. The distinction between direct and indirect taxes is based on whether or not the burden of tax can be shifted wholly or partly to others. If a tax is such that its burden cannot be shifted to others and the person who pays it to government has also to bear it is called a direct tax. Income tax, 
annual wealth tax, capital gains tax are examples of direct tax.. In case of a direct tax, there is a direct contact between the tax payer and the tax levying public authority. Indirect taxes are those taxes whose burden can be shifted to others so that those who pay these taxes to the government do not bear the whole burden but pass it on wholly or partly to others. In indirect tax there is an indirect relation between the government and those who ultimately bear the burden of the taxes (Ahuja, 2010). According to Soyode and Kajola (2015) direct tax is levied directly on the person who is expected to pay the tax. The tax payer is not only advised by notification (called assessment notice) but he is duly receipted. While indirect tax is borne by a person other than the one from whom the tax is collected. It is levied on the manufacturer but paid by the consumer. The tax payer in case of indirect tax is never notified nor have knowledge of such levy. Njoku (2009) sees direct tax as the tax imposed directly upon the person or on the property paying the tax. The tax is paid mainly on income, capital or property. Direct tax according to Chinwoke (2014) includes the following:

a. Personal income tax: This is tax paid by individuals based on their personal incomes earned over or during a certain period of time e.g. taxes paid by civil servants. It varies with the size and sources of the tax- payer 's income and various other characteristics laid down by the tax laws, such as allowances for personal, children and number of dependents, etc. the tax is progressive because higher rates are imposed on higher incomes.

b. Company income tax: This is tax levied on the profits of all incorporated business establishments (companies). The higher the profit made by a company, the higher the proportion of profit paid as tax. Companies are legal persons in the eyes of the law and therefore, they pay tax like other citizens. Company income tax is calculated after deduction of accrued interest and all revenue allowable expenses, but before the distribution of dividends. They are less prone to tax evasion and avoidance because of the federal government's insistence on the submission of tax certificates with respect to any official issue involving companies.

c. Petroleum profit tax: This tax has become an importance of government revenue since its introduction in Nigeria in 1956. This is because of the special position held by petroleum in Nigeria. It has contributed over 70 percent of the federal government's revenue from year to year. Only oil producing companies or companies engaged in oil exploration businesses are expected to pay this tax.

d. Poll tax: This is a tax levied equally on each person resident in a country, regardless of the levels of income. In Nigeria, it is mainly imposed on peasants whose tax base cannot be precisely and easily determined due to the fact that they are neither employed in the public sector or in the organized private sector e. tax paid per head in villages where all men pay the same amount as tax. It is regressive in nature.

e. Capital gains tax: This tax is levied on the gains made from the disposal of a capital asset. It is levied at the state level. Its major problem is information flow on capital transaction.

f. Capital transfer tax: This is tax levied on all properties or wealth received from another person, be he dead or alive. It is no longer applicable today in Nigeria.

Likita(1999) sees indirect tax as taxes that those who pay do not bear the entire burden of the tax but it is partially passed to consumer through higher prices. The degree by which the burden is passed to the consumer depends on the elasticity of demand for the commodity being taxed. This is levied mostly on goods and services within the economy. Indirect tax includes:

a. Excise duties: This is a tax imposed on goods that are manufactured within Nigeria. This include textile industries, sugar manufacturing companies cement companies. The total tax generated through excise tax depends on the level of industrialization of the country. In Nigeria, the amount generated is low

b. Value added tax: This was introduced in 1993. It is a tax on goods and services and can be collected at multiple stages (distribution and consumption levels). Being a consumer tax, it has the potential of raising the prices of goods and services in the economy.

c. Import duties: It is levied on goods imported into the country. This is a good source of revenue to the government of developing countries because the demand for imports is inelastic.

d. Export duties: This is the tax levied on goods exported out of the country. This method is used with caution because developing countries like Nigeria want to promote export of goods to earn more foreign exchange.

Chinwoke (2014) included specific tax which is 'tax based on the quantity purchased and ad valorem tax which is tax based on the value of goods as indirect tax.

Taxies are levied by the government on the basis of three major classes of tax rates. They are progressive, proportional and regressive. The base is the item to be taxed. It is the income being taxed in the case of income tax, the value of property in the case of property tax and the value of goods sold in the case of a sales tax. A proportional tax is one whose percentage rate remains the same as the tax base increases as a result; the amount of tax paid is proportional to the tax base while a progressive tax is one whose percentage rate increases as the 
tax base increases. A regressive tax is one whose percentage rate decreases as the tax base increases (Jhingan, 2010). The tax rate is the proportion of the tax base which must be paid in taxation to the government. It is usually expressed as a percentage (Chinwoke 2014).

For the achievement of pre-determined objectives, a good tax system must choose and adhere to certain principles. Adam Smith referred to them as cannon of taxation and they include:

i. Equality which implies taxing everybody according to his ability to pay.

ii. Certainty which means that the taxpayer should have foreknowledge of the time of payment, amount to be paid and the manner of payment. This is to avoid conflicts and disagreement between taxpayers and collectors.

iii. Convenience which means that the time, form and place of payment must be convenient to both tax payer and tax collector.

iv. Economy which means that the cost of collecting a tax must be far less than the tax paid.

v. Productivity which means that the tax system should be able to yield enough revenue for the treasury and government should have no need to resort to deficit financing,.

vi. Elasticity which implies that the tax system must be sufficiently elastic so that the government can increase or decrease it according to requirement of the state

vii. Simplicity which implies that the tax system should not be difficult to understand and administer to avoid problems of interpretation and legal disputes.

viii. Diversity which means that there is always an element of risk and uncertainty of tax revenue to enable the government to be able to absorb shocks if they occur.

ix. Flexibility which implies that the tax system should flexible enough to adjust to changes if the need be, especially during economic challenges (Okafor and Obasi, 2011).

One of the most serious problems of taxation is tax evasion and tax avoidance. Tax evasion is a deliberate attempt by the individual or corporate bodies not to pay tax, making government to lose money. Tax avoidance is a deliberate attempt by the individual or corporate bodies who tax advantages of the loopholes in the tax law to reduce the amount to be paid as tax. This fraudulent practice could be in form of declaring a loss by a company which in actual sense it is making profit. Some of the causes of tax evasion and tax avoidance include high tax rate, imperfect tax administration, complicated tax laws and information gap (Likita, 1999).

\subsection{Empirical literature}

Charles1, Ekwe and Azubuike (2018) in their study evaluated the relationship between federally collected tax revenues and Nigeria's economic growth rate between 2000 and 2016. The study adopted causal descriptive research method, and the data were drawn from annual reports of the Central Bank of Nigeria $(\mathrm{CBN})$ and Federal Inland Revenue Services (FIRS) publications. The data analysis was based on the Johansen Co-Integration test showing that a meaningful long-run relationship exists between Federally Collected Tax Revenue (FTCR) and Gross Domestic Product (GDP) of Nigeria. Specifically, Custom and Excise Duties (CED) and Value-Added Tax (VAT) and Petroleum Profit Tax (PPT) Granger caused growth rate of Gross Domestic Product (GDP). This implies that proper and efficient administration of laws of these tax components will bring the desired improvement in the tax system and will greatly enhance revenue to the government for the implementation of her policies and programmes. The study, therefore, recommends that those policies that enhance tax compliance, such as reduction in the rates of taxes; blocking of income leakages should be put in place and this will stimulate economic growth and development in the short and long run. Also, regular monitoring of the taxpayers for tax compliance as well as increased education of the taxpayers will further stimulate an increase in revenue generated through the tax system

Cornelius, Ogar and Oka (2016) examined the impact of tax revenue on the Nigerian economy. The objectives of their study were; to examine the relationship between petroleum profit tax and the Nigeria economy, the impact of company income tax on the Nigerian economy and the effectiveness of non oil revenue on the Nigerian economy. Data were sourced from Central Bank Statistical Bulletin and extracted through desk survey method. Ordinary least square of multiple regression models was used to establish the relationship between dependent and independent variables. The finding of their study revealed that there is a significant relationship between petroleum profit tax and the growth of the Nigeria economy. Their study showed that there is a significant relationship between non oil revenue and the growth of the Nigeria economy. The finding of their study also revealed that there is no significant relationship between company income tax and the growth of the Nigeria economy. The study recommended that government should endeavour to provide social amenities to all nooks and crannies of the country. Also that government should engage in a complete re-organization of the tax administrative machineries; in order to reduced tolerable problems of tax evasion and avoidance and finally, to enhance the tax base of government, employment opportunities should be created and a good environment for entrepreneurship and innovation to thrive made using tax proceeds.

Uzoka and Chinedu (2018) investigated the effect of tax revenue on economic growth of Nigeria between 
1997 -2016. The times series data sourced from Central Bank of Nigeria Statistical Bulletin and Federal Inland Revenue Service (FIRS), were analyzed using unit root tests, co-integration tests and vector error correction mechanism (VECM). The unit root test result reveals that CIT and CED and CGT are stationary at level. While real gross domestic product, petroleum profit tax, value added tax and education were stationary at first order that is after first difference. The co-integration tests (both Johansen and Engle-Granger) showed that a long run relationship existed between the economic growth and real gross domestic product, petroleum profit tax, value added tax RGDP, PPT, VAT and RDT CIT, CED. The results obtained from the analysis of the model revealed that CGT and EDT have no significant effect on economic growth while PPT, CIT, VAT and CED have significant effect on the economic growth in Nigeria. The study recommended that to boost economic growth in Nigeria, government should ensure the tax revenue generated are channeled towards building capital stock that can create more jobs which will generate more revenue to government through other forms of tax.

Appah and Ebiringa (2012) investigated the impact of petroleum profit tax on the economic growth of Nigeria. To achieve the objective of their study, secondary data were collected from the Central Bank of Nigeria (CBN) and the Federal Inland Revenue Service (FIRS) from 1970 to 2010. The secondary data collected from the relevant government agencies in Nigeria were analysed with relevant econometric tests of Breusch-Godfrey Serial Correlation LM, White Heteroskedasticity, Ramsey RESET, Jarque Bera, Johansen Co-integration, and Granger Causality. The results of their study showed that there exists a long run equilibrium relationship between economic growth and petroleum profit tax. The study also revealed that petroleum profit tax does granger cause gross domestic product of Nigeria. On the basis of the empirical analysis, their study concludes that petroleum profit tax is one of the most important components direct taxes in Nigeria that affects the economic growth of the country and therefore should be properly managed to reduce the level of evasion by petroleum exploration companies in Nigeria. Their study recommended among others that companies involved in petroleum operations should be properly supervised by the relevant tax authority (FIRS) to reduce the level of tax evasion; government should show more accountability in the management of tax revenue and finally, the level of corruption in Nigeria and that of government officials should be drastically reduced to win the confidence of tax payers for voluntary tax compliance.

Khadijat and Taophic (2018) designed a study to evaluate the effect of petroleum profit tax and company income tax on Nigerian economy growth. Fully Modified Least Square (FMOLS) Regression Technique was used to estimate the model over a 34 years period (1981-2014) while Augmented Dickey Fuller Unit Root Test and Single Equation Co-integration Test were carried out. The study discovered that petroleum profit tax (PPT) and company income tax (CIT) have positive significant impact on gross domestic product (GDP) in Nigeria with the Adjusted $\mathrm{R}^{2}$ of $87.6 \%$ which directly enhanced growth in Nigeria. The study then concluded that PPT and CIT serves as the major source of revenue to the Nigeria economy, and contribute to the growth of Nigeria economy. Based on these findings, the Study recommends that government should transparently and judiciously account for the revenue it generates through petroleum profit tax by investing in the provision of infrastructural facilities, FIRS should properly monitor the activities of companies to achieve optimum collection of taxes payable to the government as CIT. Revenue accrue to government through PPT and CIT should be judiciously used to develop the economy

Lyndon and Paymaster (2016), examined the impact of companies' income tax, value-added tax on economic growth (proxy by gross domestic product) in Nigeria. Secondary time series panel data was collected for the period 2005 to 2014 from the Statistical Bulletin of the Central Bank of Nigeria (CBN). Their study employed Ordinary Least Squares (OLS) technique based on the computer software Windows SPSS 20 version for the analysis of data, where gross Domestic product (GDP), the dependent variable and proxy for economic growth, was regressed as a function of company income tax (CIT) and value-added tax (VAT), the independent variables. The results of their analysis showed that both company income tax and value-added tax have significantly positive impact on economic growth. Based on the findings, their study recommended that government should strengthen the tax administration system to broaden the tax income, and embark on tax education to ensure voluntary tax compliance. Their study also recommended that the tax authorities should employ qualified tax professionals who should be regularly trained and be retained in the tax administration system for efficient tax administration and collection

Olaoye and Ayeni (2018) examined value added tax and customs duties on revenue generation in Nigeria. Secondary data was sourced from Federal Inland Revenue Service (FIRS) ranging from 2000 to 2016. Autoregressive Distributed Lag (ARDL) and Granger causality tests were used as the estimation techniques. The findings of the study revealed that the F-statistics value was 2.883868 which is lesser than both the lower bound and the upper bound values of 3.79 and 4.85 respectively at the 5percent level of significance which implies that there is no long run relationship among value-added tax, customs duties and revenue generation. It was equally revealed that there is no causality among value-added tax, customs duties, and revenue generation. The study concluded that value-added tax and customs duties no significant effect on revenue generation and there is no long-run relationship among value-added tax, customs duties and revenue generation in Nigeria during the study 
period. Thus the study recommended that the fiscal policy should discourage tax avoidance by emulating measures for compliance of value added tax and customs duties.

\subsection{Methodology}

Multiple regression analysis was used in the study. Time series data spanning from 1981 to 2015 was sourced from the Central Bank of Nigeria statistical bulletin. The data was analysed using E-views 9

\subsection{Model specification}

The equation specified for estimation is as follows:

$\mathrm{GDP}=\mathrm{f}(\mathrm{PPT}, \mathrm{CIT}, \mathrm{CED}$, and NR)

Equation (1) above can be transformed into an econometric model as follows:

$\mathrm{GDP}=\mathrm{b}_{0}+\mathrm{b}_{1} \mathrm{PPT}+\mathrm{b}_{2} \mathrm{CIT}+\mathrm{b}_{3} \mathrm{CED}+\mathrm{b}_{4} \mathrm{NR}+\mathrm{U}$

Where GDP = Gross domestic product (proxy for economic growth)

PPT $=$ Petroleum profit tax

CIT = Company income tax

$\mathrm{CED}=$ Custom and excise duty

$\mathrm{NR}=$ Non oil revenue

$\mathrm{U}=$ stochastic variable or error term

$\mathrm{b}_{0} \quad=\quad$ constant term

$b_{1}, b_{2}, b_{3}$, and $b_{4}=$ parameters to be estimated

\subsection{Apriori Expectation}

$b_{1}>0, b_{2}>0, b_{3}>0, b_{4}>0$

Since the data for the analysis is time series, the Augmented-Dickey Fuller (ADF) unit root test was employed to ensure data stationarity and avoid the problem of spurious regression. The Johansen test for co-integration was also employed to investigate whether there is existence of long run relationship among the variables in the model.

Table 1: Unit root test result

\begin{tabular}{|l|l|l|l|}
\hline Variables & ADF test statistic & $5 \%$ critical value & Order of integration \\
\hline GDP & -3.890566 & -2.981038 & $1(0)$ \\
\hline PPT & -5.740263 & -2.957110 & $1(1)$ \\
\hline CIT & -9.688901 & -2.954021 & $1(1)$ \\
\hline CED & -7.701009 & -2.9540221 & $1(1)$ \\
\hline NR & -7.209987 & -2.552973 & $1(1)$ \\
\hline
\end{tabular}

Source: Author's computation

The unit root test result presented on table 1 showed that GDP is stationary at levels. This is because its ADF test statistic is greater than its 5\% critical value in absolute terms. The result also showed that PPT CIT, CED and NR are all stationary at their first difference because their various ADF test statistic were greater than their $5 \%$ critical values in absolute terms. 
Table 2: Johanssen co-integration test result

Sample (adjusted): 19832015

Included observations: 33 after adjustments

Trend assumption: Linear deterministic trend

Series: GDP PPT CIT CED NR

Lags interval (in first differences): 1 to 1

Unrestricted Cointegration Rank Test (Trace)

\begin{tabular}{|c|c|c|c|c|}
\hline $\begin{array}{l}\text { Hypothesized } \\
\text { No. of CE(s) }\end{array}$ & Eigenvalue & $\begin{array}{c}\text { Trace } \\
\text { Statistic }\end{array}$ & $\begin{array}{c}0.05 \\
\text { Critical Value }\end{array}$ & Prob.** \\
\hline None * & 0.996287 & 306.0976 & 69.81889 & 0.0001 \\
\hline At most $1 *$ & 0.881974 & 121.4285 & 47.85613 & 0.0000 \\
\hline At most $2 *$ & 0.656601 & 50.91248 & 29.79707 & 0.0001 \\
\hline At most $3 *$ & 0.376613 & 15.63999 & 15.49471 & 0.0476 \\
\hline At most 4 & 0.001351 & 0.044615 & 3.841466 & 0.8327 \\
\hline
\end{tabular}

Trace test indicates 4 cointegrating eqn(s) at the 0.05 level

* denotes rejection of the hypothesis at the 0.05 level

**MacKinnon-Haug-Michelis (1999) p-values

Unrestricted Cointegration Rank Test (Maximum Eigenvalue)

\begin{tabular}{|c|c|c|c|c|}
\hline $\begin{array}{l}\text { Hypothesized } \\
\text { No. of CE(s) }\end{array}$ & Eigenvalue & $\begin{array}{c}\text { Max-Eigen } \\
\text { Statistic }\end{array}$ & $\begin{array}{c}0.05 \\
\text { Critical Value }\end{array}$ & Prob.** \\
\hline None $*$ & 0.996287 & 184.6691 & 33.87687 & 0.0001 \\
\hline At most $1 *$ & 0.881974 & 70.51607 & 27.58434 & 0.0000 \\
\hline At most $2 *$ & 0.656601 & 35.27249 & 21.13162 & 0.0003 \\
\hline At most $3 *$ & 0.376613 & 15.59538 & 14.26460 & 0.0306 \\
\hline At most 4 & 0.001351 & 0.044615 & 3.841466 & 0.8327 \\
\hline
\end{tabular}

Max-eigenvalue test indicates 4 cointegrating eqn(s) at the 0.05 level

* denotes rejection of the hypothesis at the 0.05 level

**MacKinnon-Haug-Michelis (1999) p-values

The trace test indicates that there are 4 co-integrating equations at 0.05 levels while Mac-eigenvalue test also indicates that there are 4 co-integrating equations at 0.05 levels. All these results showed that the variables are co-integrated. That is, GDP has a long run relationship with PPT, CIT, CED and NR. 
Table 3 Ordinary Least Square (OLS) Result

Dependent Variable: GDP

Method: Least Squares

Sample: 19812015

Included observations: 35

\begin{tabular}{lrlrr}
\hline \multicolumn{1}{c}{ Variable } & Coefficient & Std. Error & t-Statistic & Prob. \\
\hline C & -287.9949 & 931.7553 & -0.309089 & 0.7594 \\
PPT & 0.000119 & 0.000137 & 0.869853 & 0.3913 \\
CIT & 0.000338 & 0.000709 & 0.476554 & 0.6371 \\
CED & 0.010647 & 0.016253 & 0.655062 & 0.5174 \\
NR & 2.484533 & 0.330088 & 7.526883 & 0.0000 \\
\hline \hline R-squared & \multirow{2}{*}{0.984024} & Mean dependent var & & 20047.78 \\
Adjusted R-squared & 0.981893 & S.D. dependent var & 28383.52 \\
S.E. of regression & 3819.316 & Akaike info criterion & 19.46509 \\
Sum squared resid & $4.38 \mathrm{E}+08$ & Schwarz criterion & 19.68729 \\
Log likelihood & -335.6391 & Hannan-Quinn criter. & 19.54179 \\
F-statistic & 461.9402 & Durbin-Watson stat & 1.682001 \\
Prob(F-statistic) & 0.000000 & &
\end{tabular}

From the results of the OLS, the coefficient of PPT is positive and conforms to the aprori expectation. The coefficient of PPT which is 0.000119 implies that on the average, one unit increase in PPT will lead to 0.000119 units increase in GDP. The t-value of PPT is 0.869853 with the probability value of $0.3913>0.05$ (level of significance) shows that PPT has no significant effect on GDP in Nigeria within the period under study. For CIT, the coefficient is 0.000338 . This means that CIT is positively related to GDP and implies that on the average, one unit increase in CIT on the average to lead 0.000338 units increase in GDP. This conforms to the aprori expectation. The t-value of CIT is 0.476554 with the probability value of $0.6371>0.05$ (level of significance) shows that CIT has no significant effect on GDP in Nigeria within the period under study The result also shows that the coefficient of CED is positive and is in conformity to the aprori expectation. The result shows that on the average, one unit increase in CED will on the average lead to 0.010647 unit increase in GDP. The t-value of CED is 0.655062 with the probability value of $0.5174>0.05$ (level of significance) shows that CED has no significant effect on GDP in Nigeria within the period under study. The result equally shows that the coefficient of NR is positive and this is also in conformity to the aprori expectation. From the result one unit increase in NR will on the average lead to 2.484533 units increase in GDP. The t-value of NR is 7.526883 with the probability value of $0.0000<0.05$ (level of significance) shows NR has a significant effect on GDP in Nigeria within the period under study. The R-squared value of 0.984024 shows that about 98.2 percent of the total variations in the dependent variable (GDP) were explained by changes in the explanatory variables (PPT, CIT, CED and NR).The F-statistic of 461.9402 with the corresponding probability value of 0.0000 measured the adequacy of the regression model and the overall influence of PPT CIT, CED and NR on GDP. Since P $=0.000<0.05$ (level of significance), the model was a good fit and the explanatory variables (PPT.CIT, CED and NR) jointly exerted a statistically significant effect on the dependent variable (GDP). The Durbin-Watson value of 1.682001 which is approximately 2.000 shows the absence of autocorrelation. 
Table 4 Error Correction Results.

Dependent Variable: D(GDP)

Method: Least Squares

Sample (adjusted): 19822015

Included observations: 34 after adjustments

\begin{tabular}{|c|c|c|c|c|}
\hline Variable & Coefficient & Std. Error & t-Statistic & Prob. \\
\hline $\mathrm{C}$ & 1352.653 & 444.6198 & 3.042269 & 0.0051 \\
\hline $\mathrm{D}(\mathrm{PPT})$ & 0.000348 & $9.39 \mathrm{E}-05$ & 3.708190 & 0.0009 \\
\hline $\mathrm{D}(\mathrm{CIT})$ & 0.000284 & 0.000277 & 1.026119 & 0.3136 \\
\hline $\mathrm{D}(\mathrm{CED})$ & -0.045721 & 0.013540 & -3.376632 & 0.0022 \\
\hline $\mathrm{D}(\mathrm{NR})$ & 1.637689 & 0.280573 & 5.836936 & 0.0000 \\
\hline $\mathrm{ECM}(-1)$ & -0.523791 & 0.137267 & -3.815868 & 0.0007 \\
\hline R-squared & 0.605756 & Mean dependent var & & 2676.474 \\
\hline Adjusted R-squared & 0.535355 & S.D. dependent var & & 3257.928 \\
\hline S.E. of regression & 2220.762 & Akaike info criterion & & 18.40787 \\
\hline Sum squared resid & $1.38 \mathrm{E}+08$ & Schwarz criterion & & 18.67723 \\
\hline Log likelihood & -306.9339 & Hannan-Quinn criter. & & 18.49973 \\
\hline F-statistic & 8.604400 & Durbin-Watson stat & & 0.953116 \\
\hline Prob(F-statistic) & 0.000049 & & & \\
\hline
\end{tabular}

In the error correction result as shown on table 4, the error correction term ECM (-1) is correctly specified. It is negative and statistically significant. This means that it will be effective to correct any deviations from the long-run equilibrium. Moreover, the negative and statistically significant of the ECM confirms that the variables in the model are co- integrated The coefficient of the ECM(-1) which is -0.523791 indicates that the speed of adjustment to long run equilibrium is 52.38 percent when any past deviation must be corrected in the present period. The coefficient of determination $\left(\mathrm{R}^{2}\right)$ in error correction is 0.605758 . This means that about 60.58 percent of the variations in the dependent variable (GDP) are explained jointly by changes in the explanatory variables in the model. The F-statistic of 8.604400 with probability of 0.0000049 is significant. This means that the explanatory variables in the model PPT, CIT, CED and NR) are jointly significant. The result showed PPT, CIT and NR have a positive relationship with GDP while CED has a neghative relationship with GDP. The result equally showed that all the explanatory variables are statistically significant except CIT which is not statically significant.

4.1 Summary: The impact of tax revenue on the economic growth in Nigeria for the period $1981-2015$ has been examined in this study. The regression result showed that all explanatory variables in the model (PPT, CIT, CED and NR) have a positive impact on the economic growth of Nigeria. The result also showed that PPT, CIT and CED were not statistically significant while NR was statistically significant. The error correction result showed that all the explanatory variables have a positive relationship with economic growth except CED that has a negative relationship with economic growth. The error correction result also showed that the explanatory variables were all statistically significant except CIT which was not statistically significant. The joint effect of the explanatory variables on the dependent variable was statistically significant implying that these variables were considered important variables in explaining changes in economic growth proxy by GDP in Nigeria within the period of study. The model and operational framework of analysis exhibited a very high explanatory power, thereby providing supporting evidence that the explanatory variables included in the model were relevant in explaining changes in economic growth (GDP) in Nigeria within the period of study.

4.2 Conclusion: Given that the joint effect of the explanatory variables on the dependent variable were statistically significant, the study concludes that the explanatory variables considered in this study are important variables in explaining economic growth in Nigeria within the period of study.

4.3 Recommendations: Based on the findings, the study recommends that government agencies responsible for administration and collection of taxes should ensure that there is effective supervision and monitoring of all taxable activities so as to ensure that tax avoidance and tax evasion are reduced as this will help in generating more tax revenue for the government. Government should also ensure that all revenues collected (tax revenues and non-oil revenue) are transparently accounted for. Moreover, government should ensure tax revenues collected are used to provide adequate social amenities to the citizens as this will motivate them in complying to 
tax laws.

\section{REFERNCES}

Ahuja, H.L (2010).Macroeconomics Theory and Policy. Delhi: S.Chand \& Company limited

Anyanwu, F.A (2003).Public Finance. Owerri: CREMMD Publishers.

Anyanwu, J.C (1997).Nigerian Public Finance. Onitsha: Joanee Educational Publishers.

Anyawu, J.C (1993).Monetary Economics Theory, Policy and Institution. Onitsha: Hybrid Publishers.

Appah, E and Ebiringa, O.T (2012) Petroleum Profit Tax and Economic Growth in Nigeria. International Journal of Management Sciences and Business Research, 1(9): 12 - 32.

Bhatia, H.L (2009) Public Finance. New Delhi: Vikas Publishing House PVT Ltd.

Charles, U.J; Ekwe, M.C and Azubuike, J.U.B (2018). Federally Collected Tax Revenue and Economic Growth of Nigeria: A Time Series Analysis. International Accounting and Taxation Research Group, Faculty of Management Sciences, University of Benin, 24-38.

Chinwoke, N (2014) Public Finance in a developing world. Nigeria; Reconciliation Publishers

Cornelius, M.O; Ogar, A and Oka, F.A (2016). The Impact of Tax Revenue on Economic Growth: Evidence from Nigeria. IOSR Journal of Economics and Finance, 7(1): $32-38$.

Dewett,K.K and Navalur (2012). Modern Economic Theory. New Delhi: Rajendra Ravindra limited.

Dimoji, F.A; Atorudibo, A and Onwuneme, L.N (2013). Principles of Macroeconomics: An Introductory Text. Aba: Zemek Publishers.

Jhingan, M.L (2010). Money, Banking, International Trade and Public Finance. Delhi: Vrinda Publications Ltd

Khadijat,A.Y and Taophic, O.B (2018) Effect of Petroleum Profit Tax and Companies Income Tax on Economic Growth in Nigeria. Journal of Public Administration, Finance and Law, 13, $100-120$.

Likita, O (1999). Elements of Public Finance. Agege: Abayomi Industrial packaging ltd

Lyndon M.E and Paymaster F. B (2016). Company Income Tax and Value-Added Tax on Economic Growth: Evidence from Nigeria. European Journal of Accounting, Auditing and Finance Research, 4(7) 106-112.

Njoku, P.O (2009) Public Finance. Sources, Administration and Management. Enugu: El'demak Publishers.

Ojo, S (2008). Fundamental Principles of Nigerian Tax. Lagos: ABS Ventures

Okafor, J.C and Obasi, A (2011). Fundamentals of Macroeconomics. Enugu: Hipuks Additional Press.

Olaoye, C.O and Ayeni, O.F (2018) Effects of Value Added Tax and Custom Duties on revenue generation In Nigeria. European Journal of Accounting, Auditing and Finance Research, 6(3): 78-85.

Soyoden, O and Kajola, S.O (2015). Taxation: Principles and Practice in Nigeria. Abeokuta: Leksilicon Publishing Company.

Uzoka, P. U and Chiedu, C.O (2018). Effect of Tax Revenue on Economic Growth in Nigeria. International Journal of Social Sciences and Management Research, 4(7): 17 - 24. 